\title{
EDITORIAL
}

\section{In This Issue: An Abundance of Interven- tions and Observations to Improve Care}

\author{
Kurt C. Stange, $M D, P b D$, Editor \\ Ann Fam Med 2012;10:298-299. doi:10.1370/afm.1420.
}

W ow! The opportunities to improve practice based on new information from research are stunning. Based on research published in this issue of Annals, a family physician might:

- Train patients in mindfulness meditation and sustained exercise of moderate intensity.

Both of these interventions are associated with reduced illness severity and fewer days of missed work from acute respiratory infections in a clinical trial by Barrett and colleagues. This study also is featured in the Annals Journal Club. ${ }^{1}$

- Provide patients with access to an interactive preventive health record

In a clinical trial by Krist et al, despite fairly low rates of use among 4,500 patients in 8 primary care practices, an interactive preventive health record that provides access to the medical record, explains information in lay language, and provides individualized recommendations, resources, and reminders is associated with a greater rate of being up-to-date on recommended preventive services. ${ }^{2}$

- Offer postpartum depression screening and management.

In a randomized clinical trial by Yawn et al, physicians given postpartum screening tools and education are more likely to diagnose and treat postpartum depression, and their patients have lower depressive symptoms at 6 and 12 months of follow-up. ${ }^{3}$

- Engage in practice audit and targeted education about assessment and management of depression and self-harm in later life.

In a clinical trial by Almeida at al, this intervention had varied effects, but it reduced a composite outcome of self-harm behavior or clinically significant depression at 12 or 24 months. ${ }^{4}$

\section{SPACE IS NEEDED}

What might it take to make these interventions a reality in practice? Providing a transitional platform from the hamster wheel ${ }^{5}$ of fee-for-service payment, ${ }^{6-9}$ supporting time for reflection to balance and inform action, ${ }^{10-14}$ and involving patients in designing practice ${ }^{15-19}$ would be a good start. Capitalizing primary care practices not only to meet accreditation and performance standards but also to innovate to meet patient needs could be transformative, if practices could move from drinking from the fire hose to building adaptive reserve ${ }^{20}$ and collaborative connections, ${ }^{12,21-23}$ rather than just getting through the day. ${ }^{24-29}$

With time to reflect together and to plan, test, and learn from emerging observational research, primary care practices, their patients, and community partners might use observations from other research and reflections in this issue to strengthen patient care. They might:

- Learn from the observations of their colleagues on how to rely more on open communication and longstanding relationships than on drugs to reduce suffering in their palliative care patients. ${ }^{30}$

- Identify chemical intolerance and its comorbidities among a surprisingly high percentage of patients. ${ }^{31}$

- Work together with patients, practice colleagues, and system support to reduce opioid misuse by looking for depression ${ }^{32}$ and objective evidence of disease. ${ }^{33}$ An editorial by Von Korff provides an update on what is known and what remains to be learned, about the effectiveness and safety of opioids for chronic noncancer pain. ${ }^{34}$ In another editorial, Rosenblatt and Catlin ${ }^{35}$ provide a very helpful perspective on this challenging topic.

With some investment in time, space, and support for reflection, as well as action, and with a focus on developing adaptive reserve, communication, and partnership, the promising interventions and ideas in this issue, and ten thousand more, have a chance to make health care and health better.

We welcome your reflections at http://www.Ann FamMed.org. 


\section{References}

1. Barrett B, Hayney MS, Muller D, et al. Meditation or exercise for preventing acute respiratory infection: a randomized controlled trial. Ann Fam Med. 2012;10(4):337-346.

2. Krist AH, Woolf $\mathrm{SH}$, Rothemich SF, et al. Interactive preventive health record to enhance the delivery of recommended care: a randomized trial. Ann Fam Med. 2012;10(4):312-319.

3. Yawn BP, Dietrich AJ, Wollan P, et al. TRIPPD: a practice-based network effectiveness study of postpartum depression screening and management. Ann Fam Med. 2012;10(4):320-329.

4. Almeida OP, Pirkis J, Kerse N, et al. A randomized trial to reduce the prevalence of depression and self-harm behavior in older primary care patients. Ann Fam Med. 2012;10(4):347-356.

5. Morrison I, Smith R. Hamster health care. BMJ. 2000;321(7276): 1541-1542.

6. Bitton A, Martin C, Landon BE. A nationwide survey of patient centered medical home demonstration projects. J Gen Intern Med. 2010;25(6):584-592.

7. Merrell K, Berenson RA. Structuring payment for medical homes. Health Aff (Millwood). 2010;29(5):852-858.

8. Berenson RA, Rich EC. US approaches to physician payment: the deconstruction of primary care. J Gen Intern Med. 2010;25(6):613-618.

9. Davis K. Paying for care episodes and care coordination. $N$ Engl J Med. 2007;356(11):1166-1168.

10. Crabtree BF, Nutting PA, Miller WL, et al. Primary care practice transformation is hard work: insights from a 15-year developmental program of research. Med Care. 2011;49(Suppl):S28-S35.

11. Balasubramanian BA, Chase SM, Nutting PA, et al.; ULTRA Study Team. Using Learning Teams for Reflective Adaptation (ULTRA): insights from a team-based change management strategy in primary care. Ann Fam Med. 2010;8(5):425-432.

12. Lanham HJ, McDaniel RR Jr, Crabtree BF, et al. How improving practice relationships among clinicians and nonclinicians can improve quality in primary care. Jt Comm J Qual Patient Saf. 2009; 35(9):457-466.

13. Stroebel CK, McDaniel RR, Crabtree BF, Miller WL, Nutting PA, Stange KC. How complexity science can inform a reflective process for improvement in primary care practices. Jt Comm J Qual Patient Saf. 2005;31(8):438-446.

14. Ruhe MC, Bobiak SN, Litaker D, et al. Appreciative Inquiry for quality improvement in primary care practices. Qual Manag Health Care. 2011;20(1):37-48.

15. Greenfield S, Kaplan S, Ware JE Jr. Expanding patient involvement in care. Effects on patient outcomes. Ann Intern Med. 1985;102(4): 520-528.

16. Berwick DM. What 'patient-centered' should mean: confessions of an extremist. Health Aff (Millwood). 2009;28(4):w555-w565.

17. Epstein RM, Fiscella K, Lesser CS, Stange KC. Why the nation needs a policy push on patient-centered health care. Health Aff (Millwood). 2010;29(8):1489-1495.
18. Glen ML. Interview: Milton Seifert, MD Fam Syst Med. 1985;3(2): 221-232.

19. Seifert MH. Patient advisory council cuts malpractice costs. Patient Educ Newsl. 1984;7(5):1-2.

20. Miller WL, Crabtree BF, Nutting PA, Stange KC, Jaén CR. Primary care practice development: a relationship-centered approach. Ann Fam Med. 2010;8(Suppl 1):S68-S79, S92.

21. Fisher ES. Building a medical neighborhood for the medical home. N Engl J Med. 2008;359(12):1202-1205.

22. Grumbach K, Mold JW. A health care cooperative extension service: transforming primary care and community health. JAMA. 2009; 301(24):2589-2591.

23. Mold JW, Peterson KA. Primary care practice-based research networks: working at the interface between research and quality improvement. Ann Fam Med. 2005;3(3)(Suppl 1):S12-S20.

24. Margolis $P$, Halfon $N$. Innovation networks: a strategy to transform primary health care. JAMA. 2009;302(13):1461-1462.

25. Okie S. Innovation in primary care-staying one step ahead of burnout. N Engl J Med. 2008;359(22):2305-2309.

26. Christensen CM. Disruptive innovation: can health care learn from other industries? A conversation with Clayton M. Christensen. Interview by Mark D. Smith. Health Aff (Millwood). 2007;26(3):w288-w295.

27. Christensen CM, Baumann H, Ruggles R, Sadtler TM. Disruptive innovation for social change. Harv Bus Rev. 2006;84(12):94-101, 163.

28. Martin CM, Sturmberg JP. General practice-chaos, complexity and innovation. Med J Aust. 2005;183(2):106-109.

29. Greenhalgh T, Robert G, Macfarlane F, Bate P, Kyriakidou O. Diffusion of innovations in service organizations: systematic review and recommendations. Milbank Q. 2004;82(4):581-629.

30. Warmenhoven F, van Rijswijk E, van Hoogstraten E, et al. How family physicians address diagnosis and management of depression in palliative care patients. Ann Fam Med. 2012;10(4):330-336.

31. Katerndahl DA, Bell IR, Palmer RF, Miller CS. Chemical intolerance in primary care settings: prevalence, comorbidity, and outcomes. Ann Fam Med. 2012;10(4):357-365.

32. Grattan A, Sullivan MD, Saunders KW, Campbell Cl, Von Korff MR. Depression and prescription opioid misuse among chronic opioid therapy recipients with no history of substance abuse. Ann Fam Med. 2012;10(4):304-311.

33. Zweifler JA. Objective evidence of severe disease: opioid use in chronic pain. Ann Fam Med. 2012;10(4):366-368.

34. Von Korff MR. Opioids for chronic noncancer pain: as the pendulum swings, who shoulds set prescribing standards for primary care? Ann Fam Med. 2012;10(4):302-303.

35. Rosenblatt RA, Catlin M. Opioids for chronic pain: first do no harm. Ann Fam Med. 2012;10(4):300-301. 